\title{
Research
}

\section{Application of Structured Decision Making to an Assessment of Climate Change Vulnerabilities and Adaptation Options for Sustainable Forest Management}

\author{
$\underline{\text { Aynslie E. Ogden }}^{1,2}$ and $\underline{\text { ohn L. Innes }}^{1}$
}

\begin{abstract}
A logical starting point for climate change adaptation in the forest sector is to proactively identify management practices and policies that have a higher likelihood of achieving management objectives across a wide range of potential climate futures. This should be followed by implementation of these options and monitoring their success in achieving management objectives within an adaptive management context. Here, we implement an approach to identify locally appropriate adaptation options by tapping into the experiential knowledge base of local forest practitioners while at the same time, building capacity within this community to implement the results. We engaged 30 forest practitioners who are involved with the implementation of a regional forest management plan in identifying climate change vulnerabilities and evaluating alternative adaptation options. A structured decision-making approach was used to frame the assessment. Practitioners identified 24 adaptation options that they considered important to implement in order to achieve the regional goals and objectives of sustainable forest management in light of climate change.
\end{abstract}

Key Words: adaptation, climate change, impacts, structured decision making, sustainable forest management, vulnerability

\section{INTRODUCTION}

To date, discussions have been limited on when, where, and how to adapt to climate change in relation to sustainable management of the boreal forest. Adaptation seeks to reduce or moderate risks associated with climate change and may involve addressing increased uncertainty or anticipated climate change impacts (Ohlson et al. 2005). Adaptation planning in the forest sector is important for three main reasons: (1) climate change is already occurring in some regions where forest-based communities and forest ecosystems are vulnerable; (2) even with aggressive measures to control greenhouse gas emissions, current concentrations of greenhouse gases in the atmosphere commit the earth to continued climate change; and (3) proactive approaches to adaptation are more likely to avoid or reduce negative impacts of climate change than reactive responses (Easterling et al. 2004, Ford et al. 2006, Hare and Meinshausen 2006).
An effective policy for adaptation to climate change must be responsive to multiple objectives (Burton et al. 2002), particularly in the forest sector where socioeconomic and environmental systems are intricately linked. Integrating climate change adaptation considerations into existing decisionmaking processes is called mainstreaming and can lead to win-win policies: those that reduce vulnerability to climatic change while simultaneously addressing other priorities (Ford et al. 2006). Policies targeting climate change adaptation alone may not be practical and may not be successfully incorporated into decision-making processes (O'Brien and Leichenko 2000, Dowlatabadi 2002, 2007, Burton and Lim 2005, Lim and SpangerSiegfried 2005, Patwardhan 2006). It is important for key local actors and institutions to be involved in mainstreaming because they play a significant role in knowledge transfer and policy development (Huq et al. 2005, Newton et al. 2005, Ford et al. 2006). Adaptation strategies will be more successful if they are identified and developed by local actors 
because they are more likely to be consistent with local priorities, goals, norms, and institutions (Newton et al. 2005, Chapin et al. 2006). Conversely, a strategy that fails to consult local communities or government institutions is far less likely to be adopted (Newton et al. 2005). Forest managers also need to gain experience in developing and evaluating alternative adaptation options (Ohlson et al. 2005).

The management adaptation required to achieve sustainable forest management will differ from place to place because the vulnerabilities to climate change differ or because forest management objectives differ (Ogden and Innes 2008). Although generic adaptation options exist in the literature (e. g., Spittlehouse and Stewart 2003, Ogden and Innes $2007 \mathrm{~b}$ ), little research is being done to evaluate their applicability in a regional or applied context. Structured decision making provides a useful framework to assess when and where a particular adaptation option may be suitable (Ohlson et al. 2005, Ogden and Innes 2007b). In relation to adaptation to climate change, structured decision making involves: (1) establishing management objectives for the future forest, which are considered to be synonymous with the internationally agreedupon criteria for sustainable forest management as defined by the Montreal Process (Appendix 1; Ogden and Innes 2007b); (2) determining the vulnerability of forest ecosystems, forest communities, local economies, and human populations; (3) developing alternative adaptation options; (4) evaluating alternative options against management objectives; (5) implementing desired adaptation policies and measures; (6) monitoring the effectiveness of climate change adaptation efforts in achieving management objectives; and (7) modifying management practices when adaptation efforts are not successful in meeting management objectives (e.g., adaptive management) (Ohlson et al. 2005, Ogden and Innes 2007b).

The uncertainties associated with projections of climate change and associated impacts emphasize the need to identify robust management strategies - those that are likely to achieve the objectives of sustainable forest management and are likely to perform well across a wide range of potential future climate conditions (Ogden and Innes 2007b). Robust strategies must also be flexible and responsive to new information (Lempert et al. 2003) and, therefore, incorporate the principles of adaptive management. Robust strategies are essential for a number of reasons. Firstly, climate change scenarios are associated with irreducible uncertainties originating from a variety of factors, including a lack of information, long time scales, complexity of the climate system, measurement error, and disagreement about structural models (Moss and Schneider 2000, Kalindikar et al. 2005). Such uncertainties are best addressed by deliberately selecting alternatives that are expected to be reasonably successful for a range of scenarios and provide opportunities for learning over time. Secondly, selecting an adaptation strategy that targets a particular climate future increases the risks of maladaptation - adaptations that are not suited to future conditions or that may be more harmful than helpful.

Forestry practitioners in the Yukon and Northwest Territories of Canada were recently involved in a study to document their perspectives on the climate change impacts and adaptations for the forest sector (Ogden and Innes 2007a). The majority of practitioners in this study considered the goals of adaptation to be synonymous with the criteria of sustainable forest management, as has been suggested by current research (Spittlehouse and Stewart 2003, Ogden and Innes 2007b). These results indicate that the Montreal Process criteria (Appendix 1) provide a suitable structure for the assessment of adaptation options (Step 4 of the structured decision-making process). Practitioners who participated in the Ogden and Innes (2007a) study indicated they had difficulty in identifying adaptations for the Territories as a whole because their appropriate application depends on the magnitude, rate, and location of climate change, local management objectives, social acceptability, and economic feasibility, all of which may vary across this expansive area. This study also recommended that additional work to assess adaptation options be confined to a particular planning area where regionally defined objectives for forest management have been identified and a regional assessment of current and future vulnerabilities to climate change has been completed (Ogden and Innes 2007a).

The goal of the study reported here was to apply three steps in the structured decision-making process (assess vulnerability, develop alternative adaptation options, evaluate options against management objectives) to a regional forest management planning context. To assess vulnerabilities and options for adaptation, we 
explored the informed judgments of local forest practitioners on the following research questions:

- Assessment of vulnerabilities-Have forest practitioners observed changes in various attributes of environmental, social, and economic systems over the past 20 years that they attribute to recent climate warming? What factors do forest practitioners consider to be contributing to the adaptive capacity of the forest sector and forest-based communities to climate change? To what degree do forest practitioners consider the forest sector and forest-dependent communities as being vulnerable to the impacts of climate change?

- Assessment of adaptation options-What is the importance of alternative adaptation options to achieving the objectives of sustainable forest management under low and high scenarios of climate change? Are any of these adaptation options currently being practiced? Which management options are likely to perform well across a range of potential future climate change scenarios? Is the framework suggested by Ogden and Innes (2007b) useful to an evaluation of adaptation options in a regional forest management context?

\section{STUDY AREA - CHAMPAGNE AND AISHIHIK TRADITIONAL TERRITORY, SOUTHWEST YUKON}

The study area encompassed the Champagne and Aishihik First Nations Traditional Territory (CATT) in southwest Yukon, Canada (Fig. 1). Accumulating evidence suggests that this region is already experiencing the impacts of climate change: warmer winters and warmer and drier summers over the past 15 years have contributed to a severe spruce beetle (Dendroctonus rufipennis) outbreak, affecting almost 400000 ha of white spruce (Picea glauca) forest (of an estimated $600000 \mathrm{ha}$ ) in the traditional territory (Arctic Climate Impact Assessment (ACIA) 2004, Garbutt 2005, Ogden 2007). This is the largest and most intense outbreak of spruce beetle ever to affect Canada (ACIA 2004). Although climate has played a critical role in increasing the population of beetles to epidemic levels and weakening the defenses of the spruce trees, the infestation has been exacerbated by the large tracts of mature white spruce that characterize the forests in this region. Since the mid-1990s, the spruce beetle outbreak has been driving forest management and planning efforts in the affected region.

Governance of forest resources in the Yukon is unique due to the existence of modern First Nation Land Claim and Self-Government agreements. In 1993, the Final Agreement between Champagne and Aishihik First Nations (CAFN), the Government of Canada, and the Government of Yukon was signed. The agreement assigned rights to CAFN to co-manage traditional lands and resources within its traditional territory and ownership of $2427 \mathrm{~km}^{2}$ of land. As mandated by the agreement, the Alsek Renewable Resource Council (ARRC) was established in 1995 to provide recommendations on the management of fish, wildlife, and forest resources to governments and to be a voice for local community members in renewable resource management.

In December 2004, the Strategic Forest Management Plan (SFMP) for the CATT was jointly approved by the CAFN and the Government of Yukon (ARRC 2004). The plan identifies reduction of fire hazard, renewal of beetle-killed forests, provision of economic benefits, and preservation of wildlife habitat as priorities. The SFMP explicitly incorporates a commitment to an adaptive management framework that includes monitoring the effects of forest management activities and modifying practices as necessary to ensure that the objectives are being met. Recently, an Integrated Landscape Plan (ILP) was released that established the Forest Resource Management Zone where forest development planning may take place (Government of Yukon and CAFN 2007; Fig. $1)$. The focal area for this project was this zone, which is approximately 93700 ha (38\% of the forest area, $4.8 \%$ of the traditional territory). In April 2006, CAFN and the Government of Yukon jointly set a harvest level for this zone for up to $1000000 \mathrm{~m}^{3}$ of beetle-affected timber over 10 years.

The southwest Yukon provides an ideal case study for research into adaptation policies. The impacts of climate change on the forests are forcing changes to the social and economic sectors of local communities that are dependent on the goods and services provided by these forests. Climate change impacts are likely to affect whether or not the goals 
Fig. 1. Study area-the Champagne and Aishihik First Nations Traditional Territory in southwest Yukon, Canada (Source: Government of Yukon).

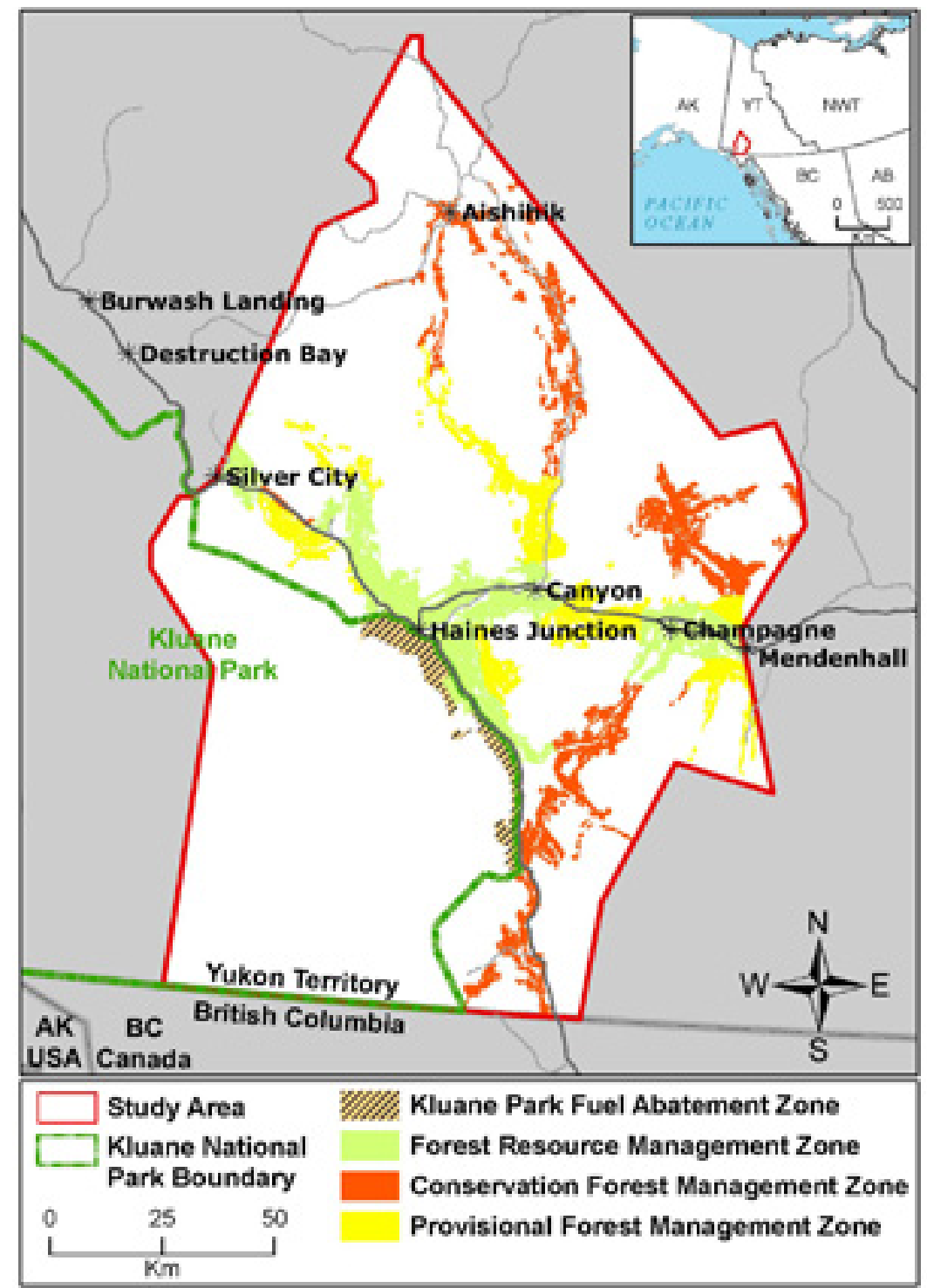

of the community-directed SFMP, which include having functioning forest ecosystems and providing community sustainability and benefits, can be achieved (Ogden 2007). The spruce bark beetle infestation has heightened awareness of the often abstract issue of climate change among local communities and management agencies, providing a rallying point to explore adaptation planning. The strategic plan also identifies goals of cooperative forest management and planning and building local capacity that, along with the commitment to adaptive management, provide the vehicle and forum to make management decisions that incorporate climate change considerations. Local agencies responsible for SFMP implementationGovernment of Yukon, CAFN, and the ARRChave expressed an interest in research that can inform plan implementation as evidenced by their 
establishment of a technical working group devoted to research and monitoring. Few examples of community-directed and co-managed approaches to forest management exist in the boreal forest, and therefore, this project provides opportunities for learning in a broader context. Lastly, an interdisciplinary and collaborative synthesis of existing knowledge on the impacts of climate change on forest resources has been completed for the region that helps set the stage for adaptation policy research (Ogden 2007).

\section{METHODS}

\section{Project Planning Team}

Several lessons have emerged from experiences with research and resource co-management that are essential to the design of any policy research project in the southwest Yukon. They include the necessity of understanding other actors' standpoints and perspectives, the limited prospects for importing ideas about resource management from elsewhere, the need for place-based social learning, and the need to strengthen trust between community and government partners (Wortley 2003, Clarke and Slocombe 2004). Given this experience, participatory research approaches were considered appropriate for this study. Participatory research has the potential to enhance willingness, capacity, and understanding among participants, which are essential to successful decision making in resource management (Gunderson and Holling 2002). A project planning team-consisting of researchers at the University of British Columbia (UBC), representatives of the CAFN Lands and Resources Department, and the Government of Yukon Forest Management Branch-was established to guide the planning and implementation of the research. The project team reviewed, revised, and approved the project proposal, identified participants, helped to secure funding, participated in the pilot session, and advised on a plan for the dissemination of results.

\section{The Forest Practitioner Target Group}

The project involved documenting the informed judgments of local forest practitioners who are involved with the planning and management of forest resources. Forest practitioners are highly knowledgeable individuals whose employment or livelihood is tied to the forest sector. Taking into account the northern context of the project, our working definition of a forest practitioner was purposefully broad so as to encompass those with social, cultural, economic, or environmental expertise, and holders of local, traditional, or scientific knowledge of forest resources.

The forest practitioners targeted in this study were all involved in some way with the implementation of the CATT SFMP. These practitioners play an important role in developing, implementing, and reviewing operational forest management plans to ensure the community-directed goals and objectives of forest management are achieved. Practitioners were identified using non-probability, purposive, or judgmental sampling methods as the small population size did not permit probability-based sampling techniques (Babbie and Benaquisto 2002). Fifty-nine practitioners were identified and included individuals employed by First Nation, territorial, and federal governments, co-management organizations, industry, and academic and nongovernmental organizations.

\section{Data Collection}

Each participant completed a workbook that took 1 day to complete. Five identical sessions were held, each consisting of six to eight people, to facilitate the completion of the workbooks. The purpose of the sessions was to ensure there was a common understanding among participants of the questions being asked in the workbook. As we were interested in gaining an understanding of the range of opinions among practitioners, no attempt was made to reach consensus on any of the questions. A pilot test for the sessions was undertaken that identified a number of modifications that were needed to the workbook (e.g., wording of questions, reducing the number of questions). Efforts were made to create a comfortable, non-judgmental, permissive environment and to place individuals within groups where participants were likely to share common ideas. The sessions were moderated by a neutral, skilled facilitator who was familiar with the subject matter. At the start of the session, the facilitator introduced the goals and objectives of the research project. Throughout the day, the facilitator introduced the various sections of the workbook and encouraged discussion on the nature and intent of the questions to ensure they were commonly understood. After each section of the workbook was introduced, the practitioners were given time to complete that 
section of the workbook. Discussions on individual responses to the questions in the workbook were limited so as to not influence the responses being provided by the participants.

\section{Participant Workbook}

The sequence of questions in the participant workbook followed the structured decision-making approach described above. Although participants completed the workbook during the session, the workbook was designed to be self-administered. The workbook was 65 pages in length and included the following sections:

- Establishment of goals and objectives

- Assessment of climate change vulnerabilities

- Identification and evaluation of alternative management options

- Identification of alternative forest renewal adaptation strategies

- Evaluation of alternative strategies by forest management objectives in the CATT

- Application of alternative strategies to CATT landscape zones

- Identification of key uncertainties and research needs

This paper concentrates on the analysis of the responses concerning the assessment of vulnerabilities and the evaluation of alternative management options.

\section{Climate scenarios}

Participants were provided with climate normals and scenarios of climate change for the region obtained from Environment Canada's Weather Office and Climate Change Scenarios Network. Climate normal data from the nearest weather station to the study area with a complete record, Burwash Landing, were referenced. Between the periods 1951-1988 and 1971-2000, climate normals show an increase in annual mean temperature and a decrease in total annual precipitation. There are 32 climate scenarios available for the southern Yukon. To represent the range of possible future conditions, the 32 scenarios were ranked from lowest to highest according to the change in annual temperature and precipitation. The lower and upper estimates of future change that were used were the 4th and 29th ranking respectively following Burn et al. (2004). These "low" and "high" scenarios of future change were used throughout the workbook as described further below. Climate scenarios agree that the Yukon will become warmer over the next 50 years, and more precipitation is projected. Participants were alerted to the uncertainty associated with the climate scenarios (e.g., as discussed by Bonsal et al. 2003).

\section{Assessment of vulnerabilities}

We then explored the informed judgments of forest practitioners on vulnerabilities of the forest sector and forest-dependent communities to climate change in the study area. The Intergovernmental Panel on Climate Change (IPCC) definitions of vulnerability, sensitivity, and adaptive capacity were used to structure the questioning in this section (IPCC 2001). We provided practitioners with a list of observed climate change impacts on northern forested ecosystems, and associated socioeconomic systems, that we compiled from relevant literature (IPCC 2001, ACIA 2004, Lemmen and Warren 2004), including two local projects (McKinnon 2006, Ogden 2007). We asked practitioners to provide their judgment on the extent to which changes in these systems had been observed in the region over the past 20 years in response to recent climatic warming as an indication of sensitivity. We then asked practitioners to provide an indication of the adaptive capacity of the region by indicating the extent to which they considered various factors that influence adaptive capacity (from IPCC 2001, Berkes and Jolly 2002, Folke et al. 2002, Yohe and Tol 2002, Smit and Pilifosova 2003) to be present in the region. Practitioners then provided their judgment on the degree to which the forest sector and forest-dependent communities in the CATT are vulnerable to climate change impacts. Practitioners were asked to assess current vulnerability based on changes observed to date in the region. Then, practitioners were asked to evaluate vulnerability for low and high scenarios of future climate change. Participants were given the opportunity to revise and add to the list of climate change impacts and factors influencing adaptive capacity during the session. 


\section{Identification and evaluation of alternative management options}

Practitioners evaluated 84 adaptation options. The adaptation options were structured using the framework developed by Ogden and Innes (2007b) that organized adaptation according to the criteria of the Montreal Process. The Montreal Process criteria are complementary to the goals and objectives of the CATT SFMP. The use of this structure enabled comparisons to be made between this project and a recent survey of practitioners in the Yukon and Northwest Territories that also applied this framework (Ogden and Innes 2007a).

As a starting point, we asked practitioners to indicate which of the adaptation options were currently being practiced in the Yukon because an understanding of current management practices that may contribute to reducing vulnerability to climate change may help bring into focus the incremental costs and benefits of additional adaptation measures (Ohlson et al. 2005). Practitioners were also invited to suggest any additional adaptation options. Then we sought their opinion on the importance of implementing these options under current climate conditions and under low and high scenarios of projected climate change. In evaluating the options, practitioners were asked to consider how important it would be to implement these in areas that are subject, or will be subject to, forest development planning in the region, specifically the 93 700-ha forest resource management zone identified in the regional Integrated Landscape Plan.

An adaptation option was considered important if the average ranking was $\geq 7 / 10$. We looked for robust or "no regrets" adaptation options, defined as those that were considered by the group of practitioners as a whole to be important to implement across a wide range of possible future climate conditions (as indicated by an average ranking of importance of $\geq 7 / 10$ for all three scenarios). Similarly, management options considered unimportant under any scenario (average ranking $\leq 3 / 10$ for all three scenarios) were identified; we term these "no go" options.

\section{RESULTS}

\section{Participant Information}

A total of 30 practitioners completed their workbooks. The majority of participants (53\%) were employed by territorial government agencies, $20 \%$ by the federal government, $13 \%$ by the First Nations Government, and $10 \%$ by a NGO. When asked which of the pillars of sustainable forest management - environmental, economic, social, or cultural - their work was most concerned with, 53\% of practitioners indicated all of the above, and $47 \%$ indicated environmental. Most participants were highly experienced: $53 \%$ indicated they have been a forest practitioner for more than 16 years, $17 \%$ indicated they have 11-15 years of experience, and $20 \%$ indicated they have 6-10 years of experience. In addition, many (54\%) participants indicated they have lived/worked in the Yukon for 11 years or more. Because the sample size was too small to enable an exploration of differences in judgments from practitioners with different backgrounds, the data were merged into a single data set for analysis.

\section{Assessment of Vulnerabilities}

Participants were asked to provide their judgment on the extent to which 15 climate change impacts have been observed in the CATT over the past 20 years in response to recent changes in regional climate conditions (Table 1). All suggested impacts were noted by at least some of the practitioners as having been observed. The most notable impact was a change in the intensity, severity, or magnitude of forest insect outbreaks; specifically, the spruce beetle infestation. In addition to the list in the workbook, participants noted that over the past 20 years, changes had been observed in timber quality, water levels (e.g., lakes, rivers, wetlands), keystone species and the species they interact with (e.g., woodpeckers), understory species, including trees below the canopy, soil microbial activity, and the distribution of permafrost.

Participants indicated the extent to which a number of factors that contribute to enhancing the adaptive capacity of the forest sector and forest-based communities to climate change are present in the CATT. These are summarized in Table 2. Participants did not consider any of the listed factors as being particularly prevalent. Family-level 
Table 1. Judgments of forest practitioners on the degree of change in various attributes of environmental, social, and economic systems observed over the past 20 years in the Champagne and Aishihik Traditional Territory in response to recent climate warming. Scale of 1 to $10(0=$ no change, $1=$ low, $10=$ high $)$ or don't know. Results shown are the average rank and standard deviation (s.d.) of participants who provided a ranking and number of participants who indicated that they don't know.

\begin{tabular}{lll}
\hline \hline Climate Change Impact & $\begin{array}{l}\text { Average Rank } \\
\text { (s.d.) }\end{array}$ & $\begin{array}{c}\text { Don't } \\
\text { Know }\end{array}$ \\
\hline Changes in the frequency, intensity, severity, or magnitude of forest fires & $4.5(3.4)$ & 1 \\
Changes in the frequency, intensity, severity, or magnitude of forest insect outbreaks & $8.1(2.4)$ & 0 \\
Changes in extreme weather events (heavy winds, lightning, winter storms, drought) & $5.5(2.4)$ & 5 \\
Changes in forest growth and productivity & $4.9(2.8)$ & 3 \\
Changes in phenology & $5.0(2.4)$ & 8 \\
Changes in wildlife species abundance, movement, and ranges & $4.7(2.6)$ & 3 \\
Changes in abundance and ranges of invasive species & $5.0(3.2)$ & 5 \\
Change in forest cover type & $4.4(3.1)$ & 1 \\
Changes in treeline & $3.2(2.6)$ & 5 \\
Changes in timber supply & $5.4(3.4)$ & 2 \\
Changes in the availability of non-timber forest products & $3.4(2.9)$ & 8 \\
Changes in land values and land-use options & $4.7(3.3)$ & 3 \\
Changes in economic opportunities & $4.4(3.20$ & $5.2(2.8)$ \\
Change in length of winter road season & $3.1(2.4)$ & 7 \\
Changes in livelihood & & 7 \\
\hline
\end{tabular}

resistance to lifestyle change, poor access to local and traditional knowledge (there is a rich supply but is not easily accessed), and the lack of identified markets for local forest products were also identified as potentially reducing adaptive capacity in the region.

Judgments on the degree to which forest sector and forest-dependent communities in the CATT are vulnerable to various impacts of climate change were recorded in the context of the three scenarios of climate change. These are summarized in Table 3. Currently, participants consider the region to be highly vulnerable to changes in the intensity, severity, or magnitude of insect outbreaks and forest fires and moderately vulnerable to changes in extreme weather events, timber supply, and wildlife abundance, movement, and ranges. Vulnerability was considered to increase with increasing warming for all of the potential impacts. Under a high scenario of climate change, the region was considered to be highly vulnerable to two-thirds of the impacts considered. Vulnerability to changing forest fire regimes aroused considerable concern, generating more comment than any other impact. Many noted that although at present a change in the fire regime (e.g., number of fires, area burned) has not been observed in the region, the hazard is seen 
Table 2. Judgments of forest practitioners on the degree to which various factors that contribute to enhancing the adaptive capacity of the forest sector and forest-based communities to climate change are present in the Champagne and Aishihik Traditional Territory. Results provide an indication of whether the factor is high or low in the region. Scale of 1 to $10(0=$ no contribution, $1=$ low contribution, $10=$ high contribution $)$ or don't know. Results shown are the average rank and standard deviation (s.d.) of participants who provided a ranking and number of participants who indicated that they don't know.

Factor Influencing Adaptive Capacity

Current level of awareness and understanding of climate change impacts

Current level of awareness and understanding of options to adapt to climate change

Current level of diversity of the forest economy

Degree of substitutability of non-timber forest resources

Cumulative effects of resource developments and other forces of change

Availability of informed, skilled, and trained personnel

Availability of scientific knowledge on climate change

Availability of local and traditional knowledge on climate change

Current level of investment in training, education, capacity building, knowledge exchange, technology transfer

Current allocation of investments in research and innovation

Current level of dialog among various decision-making agencies and stakeholders on adaptation

Current level of flexibility in forest management policies and practices

Current level of consideration of adaptation-related issues in forest management and planning

Availability of financial resources to adapt to climate change

\section{Average Rank (s.d.)}

$5.7(2.7)$

$4.5(2.6)$

$4.2(3.0)$

$4.8(2.9)$

$5.1(2.6)$

$4.6(2.6)$

$6.1(1.7)$

5.5 (2.3)

4.1 (3.0)

$4.2(2.8)$

3

$5.6(2.8)$

0

5.4 (3.2)

0

$5.3(2.6)$

0

$3.9(3.1)$
1

7

Don't

Know

1

(1)

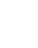

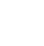


Table 3. Judgments of forest practitioners on the degree to which the forest sector and forest-dependent communities in the Champagne and Aihihik Traditional Territory are vulnerable to the following impacts of climate change. Vulnerability is the extent to which climate change may damage or harm a system. It depends on a system's sensitivity and ability to adapt to new climate conditions. Scale of 1 to $10(0=$ not vulnerable, $1=$ low vulnerability, $10=$ high vulnerability) or don't know. Results shown are the average rank and standard deviation (s.d.; in parentheses) of participants who provided a ranking.

\begin{tabular}{|c|c|c|c|}
\hline Climate change impact & $\begin{array}{l}\text { Current } \\
\text { vulnerability }\end{array}$ & $\begin{array}{l}\text { Future vulnerability: } \\
\text { "low scenario" of } \\
\text { climate change }\end{array}$ & $\begin{array}{l}\text { Future vulnerability: } \\
\text { "high scenario" of } \\
\text { climate change }\end{array}$ \\
\hline $\begin{array}{l}\text { Changes in the intensity, severity, or magnitude of } \\
\text { forest fires }\end{array}$ & $7.1(2.4)$ & $7.4(2.1)$ & $8.3(2.4)$ \\
\hline $\begin{array}{l}\text { Changes in the intensity, severity, or magnitude of } \\
\text { forest insect outbreaks }\end{array}$ & $6.7(2.7)$ & $7.0(2.6)$ & $8.0(2.8)$ \\
\hline $\begin{array}{l}\text { Changes in extreme weather events (heavy winds, } \\
\text { lightning, winter storms, drought) }\end{array}$ & $6.1(1.9)$ & $6.9(1.8)$ & $8.2(1.6)$ \\
\hline Changes in forest growth and productivity & $4.8(3.0)$ & $5.9(2.7)$ & $7.5(2.6)$ \\
\hline Changes in phenology & $5.1(2.7)$ & $5.6(2.8)$ & $6.7(2.8)$ \\
\hline $\begin{array}{l}\text { Changes in wildlife species abundance, movement, and } \\
\text { ranges }\end{array}$ & $5.5(2.1)$ & $6.7(2.0)$ & $8.0(2.0)$ \\
\hline Changes in abundance and ranges of invasive species & $4.9(2.6)$ & $6.1(2.6)$ & $7.4(2.7)$ \\
\hline Change in forest cover type & $4.7(2.4)$ & $5.7(2.4)$ & $7.3(2.5)$ \\
\hline Changes in treeline & $3.8(2.4)$ & $4.5(2.6)$ & $5.8(2.9)$ \\
\hline Changes in timber supply & $5.6(2.5)$ & $6.0(2.8)$ & $7.1(2.6)$ \\
\hline $\begin{array}{l}\text { Changes in the availability of non-timber forest } \\
\text { products }\end{array}$ & $4.5(1.7)$ & $5.5(2.0)$ & $6.7(2.0)$ \\
\hline Changes in land values and land-use options & $4.5(2.5)$ & $5.0(2.6)$ & $5.5(2.6)$ \\
\hline Changes in economic opportunities & $4.7(2.3)$ & $5.5(2.3)$ & $6.5(2.7)$ \\
\hline Change in length of winter road season & $4.7(2.4)$ & $6.1(2.6)$ & $7.4(2.7)$ \\
\hline Changes in livelihood & $3.8(2.2)$ & $5.0(2.5)$ & $5.9(3.0)$ \\
\hline
\end{tabular}

implement under current climate conditions, two under a low scenario of climate change, and six under a high scenario. Many noted that because little area in the region is currently impacted by development, adaptation options such as minimizing the fragmentation of habitat, maintaining representative forest types, and protecting primary forests were happening by default. However, several noted that they do not consider this to be the same as "current practice," which to them implies a more formal policy, regulation, or land-use designation.

It was noted that it may not be possible to maintain representative forest types in reserves, and some questioned whether this was desirable or necessary 
Table 4. Judgments of forest practitioners on the importance of adaptation options to conserve biological diversity in the Champagne and Aishihik Traditional Territory for each of three scenarios: "current climate conditions," "low scenario of future climate change by the 2050s," and "high scenario of future climate change by the 2050s." Scale of 1 to $10(0=$ no importance, $1=$ low importance, $10=$ high importance $)$ or don't know. Results shown are the average rank and standard deviation (s.d.) of participants who provided a ranking. The percentage of participants who agree or strongly agree with the statement "this management option is currently being practiced in the Yukon" is also provided. Adaptation options in bold are considered to be "no-regrets" (option is ranked 7 or higher across range of scenarios).

\begin{tabular}{|c|c|c|c|c|}
\hline \multirow[t]{3}{*}{ Adaptation Option } & \multicolumn{2}{|c|}{$\begin{array}{l}\text { Current Current } \\
\text { Practice Importance }\end{array}$} & \multicolumn{2}{|c|}{$\begin{array}{l}\text { Importance Considering } \\
\text { Projected Change } 2050 \mathrm{~s}\end{array}$} \\
\hline & & & $\begin{array}{l}\text { Low } \\
\text { Scenario }\end{array}$ & $\begin{array}{l}\text { High } \\
\text { Scenario }\end{array}$ \\
\hline & $(\%)$ & $\begin{array}{l}\text { Average Rank } \\
\text { (s.d.) }\end{array}$ & $\begin{array}{l}\text { Average } \\
\text { Rank } \\
\text { (s.d.) }\end{array}$ & $\begin{array}{l}\text { Average } \\
\text { Rank } \\
\text { (s.d.) }\end{array}$ \\
\hline Minimize fragmentation of habitat and maintain connectivity & 60 & $7.1(2.7)$ & $7.5(2.6)$ & $7.8(2.6)$ \\
\hline $\begin{array}{l}\text { Maintain representative forest types across environmental gradients } \\
\text { in reserves }\end{array}$ & 46 & $6.4(2.7)$ & $6.9(2.8)$ & $7.0(3.0)$ \\
\hline $\begin{array}{l}\text { Protect primary forests (forests that are largely undisturbed by } \\
\text { human activities) }\end{array}$ & 37 & $6.0(3.3)$ & $6.1(3.4)$ & $6.5(3.3)$ \\
\hline Protect climate refugia at multiple scales & 16 & $5.7(3.5)$ & $6.6(3.3)$ & $7.1(3.4)$ \\
\hline Identify and protect functional groups and keystone species & 47 & $6.7(2.8)$ & $7.2(2.4)$ & $7.8(2.4)$ \\
\hline Maintain natural fire regimes & 60 & $5.9(3.0)$ & $6.0(3.2)$ & $6.4(3.1)$ \\
\hline Provide buffer zones for adjustment of reserve boundaries & 36 & $5.4(3.5)$ & $5.7(3.6)$ & $6.0(3.7)$ \\
\hline Create artificial reserves or arboreta to preserve rare species & 20 & $4.6(2.8)$ & $5.3(2.8)$ & $5.8(2.8)$ \\
\hline Protect most highly threatened species ex situ & 33 & $4.3(3.2)$ & $5.2(3.3)$ & $5.7(3.4)$ \\
\hline $\begin{array}{l}\text { Develop a gene management program to maintain diverse gene } \\
\text { pools }\end{array}$ & 10 & $5.5(2.8)$ & $6.5(2.8)$ & $7.1(2.9)$ \\
\hline Allow forests to regenerate naturally following disturbance & 90 & $5.1(3.2)$ & $4.9(3.1)$ & $5.1(3.4)$ \\
\hline Control invasive species & 13 & $5.9(3.0)$ & $6.5(3.0)$ & $7.2(3.2)$ \\
\hline $\begin{array}{l}\text { Practice low-intensity forestry and prevent conversion to } \\
\text { plantations }\end{array}$ & 50 & $5.6(3.2)$ & $5.9(3.2)$ & $6.1(3.5)$ \\
\hline $\begin{array}{l}\text { Assist changes in the distribution of species by introducing them to } \\
\text { new areas }\end{array}$ & 33 & $3.6(2.6)$ & $4.7(2.9)$ & $5.7(3.2)$ \\
\hline
\end{tabular}


Table 5. Judgments of forest practitioners on the importance of adaptation options to maintain the productive capacity of forest ecosystems in the Champagne and Aishihik Traditional Territory for each of three scenarios: "current climate conditions," "low scenario of future climate change by the 2050s," and "high scenario of future climate change by the 2050s." Scale of 1 to $10(0=$ no importance, $1=$ low importance, $10=$ high importance) or don't know. Results shown are the average rank and standard deviation (s.d.) of participants who provided a ranking. The percentage of participants who agree or strongly agree with the statement "this management option is currently being practiced in the Yukon" is also provided. Adaptation options in bold are considered to be "no-regrets" (option is ranked 7 or higher across range of scenarios).

\begin{tabular}{|c|c|c|c|c|}
\hline \multirow[t]{3}{*}{ Adaptation Option } & \multicolumn{2}{|c|}{$\begin{array}{l}\text { Current Current } \\
\text { Practice Importance }\end{array}$} & \multicolumn{2}{|c|}{$\begin{array}{l}\text { Importance Considering } \\
\text { Projected Change 2050s }\end{array}$} \\
\hline & & & Low Scenario & High Scenario \\
\hline & $(\%)$ & $\begin{array}{l}\text { Average Rank } \\
\text { (s.d.) }\end{array}$ & $\begin{array}{l}\text { Average Rank } \\
\text { (s.d.) }\end{array}$ & $\begin{array}{l}\text { Average Rank } \\
\text { (s.d.) }\end{array}$ \\
\hline $\begin{array}{l}\text { Practice high-intensity plantation forestry in selected areas to } \\
\text { promote growth of commercial tree species. }\end{array}$ & 10 & $4.3(3.4)$ & $5.1(3.2)$ & $5.9(3.3)$ \\
\hline Assist in tree regeneration & 53 & $5.6(2.2)$ & $6.3(3.0)$ & $7.1(2.7)$ \\
\hline Employ vegetation control techniques to offset drought & 3 & $3.7(2.3)$ & $4.9(2.4)$ & $6.0(2.9)$ \\
\hline $\begin{array}{l}\text { Plant genetically modified species and identify more suitable } \\
\text { genotypes }\end{array}$ & 7 & $4.2(3.6)$ & $5.0(3.5)$ & $5.7(3.5)$ \\
\hline Enhance forest growth through forest fertilization & 0 & $1.6(2.2)$ & $2.1(2.4)$ & $2.4(2.8)$ \\
\hline $\begin{array}{l}\text { Apply silvicultural techniques that maintain a diversity of age } \\
\text { stands and mix of species }\end{array}$ & 66 & $7.6(1.9)$ & $8.2(1.6)$ & $8.5(1.6)$ \\
\hline Actively manage forest pests & 7 & $4.4(3.2)$ & $5.0(3.3)$ & $5.5(3.7)$ \\
\hline $\begin{array}{l}\text { Underplant with other species or genotypes where the current } \\
\text { advanced regeneration is unacceptable as a source for the future } \\
\text { forest }\end{array}$ & 7 & $4.1(3.8)$ & $4.8(3.6)$ & $5.4(3.5)$ \\
\hline $\begin{array}{l}\text { Selectively remove suppressed, damaged, or poor-quality } \\
\text { individuals to increase resource availability to the remaining trees } \\
\text { (precommercial thinning) }\end{array}$ & 7 & $4.1(3.6)$ & $4.6(3.4)$ & $5.1(3.4)$ \\
\hline $\begin{array}{l}\text { Reduce the rotation age followed by planting to speed the } \\
\text { establishment of better-adapted forest types }\end{array}$ & 16 & $3.4(3.3)$ & $4.1(3.2)$ & $4.8(3.4)$ \\
\hline $\begin{array}{l}\text { Control those undesirable plant species that will become more } \\
\text { competitive in a changed climate }\end{array}$ & 13 & $4.1(2.8)$ & $5.2(2.7)$ & $5.9(3.0)$ \\
\hline $\begin{array}{l}\text { Relax rules governing the movement of seed stocks from one area } \\
\text { to another; examine options for modifying seed transfer limits and } \\
\text { systems }\end{array}$ & 20 & $3.3(3.1)$ & $4.3(2.9)$ & $5.0(3.2)$ \\
\hline $\begin{array}{l}\text { Include climate variables in growth and yield models in order to } \\
\text { have more specific predictions on the future development of } \\
\text { forests }\end{array}$ & 33 & $6.7(2.9)$ & $7.5(2.3)$ & $8.2(2.1)$ \\
\hline
\end{tabular}




\begin{tabular}{|c|c|c|c|c|}
\hline $\begin{array}{l}\text { Design and establish a long-term multi } \\
\text { improved genotypes across a diverse at } \\
\text { latitudinal environments }\end{array}$ & 30 & $6.4(2.8)$ & $7.0(2.3)$ & $7.7(2.3)$ \\
\hline Minimize disturbance to forest soils & 70 & $7.6(2.8)$ & $7.9(2.6)$ & $8.2(2.5)$ \\
\hline
\end{tabular}

given the difficulties involved. What the definition of functional groups and keystone species should be in light of climate change was also questioned. It was suggested that it will be important to monitor how climate change and, in particular, associated changes in disturbance regimes may be driving changes in forest succession and, in turn, how changes in succession are impacting species that are critically associated with particular habitat types. For example, many noted that they suspect major shifts in the ecosystems in this region are inevitable because of climate change and suggested the possibility of forest types in the region shifting to grassland ecosystems.

In the near term, greater effort to reduce the amount of forest fuels was considered necessary. Fuels are flammable woody materials that increase the crowning potential of forest fires. Crown fires are more difficult to control and, therefore, pose a greater risk to communities. Fuel reduction was considered particularly important for the dead spruce stands around communities; in these areas, most practitioners agree that natural fire regimes should not be maintained due to values at risk. However, at a landscape scale, practitioners indicated that fuel-reduction efforts need to find a more appropriate balance with biodiversity-related concerns. The maintenance of natural fire regimes was seen as necessary by some to reduce the potential for catastrophic fire as long-term fire suppression would contribute to a decline in biodiversity and the build-up of fuels (unless it is accompanied by other methods of fuel reduction such as prescribed burning or mechanical harvests). The use of prescribed burning as a habitat management tool was also suggested as worthy of further exploration.

An influx of invasive species is expected, and many questioned how feasible it will be to control these. Others questioned whether the term invasive applies to species whose range is shifting north as a result of climate change and noted that efforts to facilitate the introduction of species into the region is a management option that is not likely to be popular with local residents. The need for adequate research on the potential impacts of planned introductions was noted. Although it was recognized that facilitating the westward migration of tree species into the region that are already present in the Yukon and are likely to do well in a changing climate (e. g., lodgepole pine (Pinus contorta var. murrayana)) may be advantageous in meeting some timber production-oriented management objectives, such a strategy may conflict with other biodiversityrelated objectives. The importance of an assessment of the cumulative impacts of climate change and resource development on the long-term conservation of biodiversity was emphasized by several practitioners.

\section{Adaptation options to maintain productive capacity of forest ecosystems}

Various options have been suggested by researchers to maintain the productive capacity of forest ecosystems in the CATT (Table 5). Of the 15 options, two were considered to be important under current climate conditions, four under a low scenario of climate change, and five under a high scenario. There was no consensus over the use of high-intensity plantation forestry in selected areas as a way to promote the growth of commercial tree species in a changing climate. Some felt that this might be useful in specific locations to enable longterm forestry activities and that it might alleviate the pressure to use other areas. Others noted that all forests used for timber production should meet minimum criteria for in-block retention, riparian reserve zones, unlogged connected areas, etc.

For some, assisting in tree regeneration was only seen as necessary where natural regeneration fails. It was noted that in the past, regeneration had been partially funded by industry but at a level below that needed to plant at all sites. Genetically modified seeds have not been planted in the Yukon, and many participants distinguished between the desirability of planting genetically modified species and species 
Table 6. Judgments of forest practitioners on the importance of adaptation options to maintain health and vitality of forest ecosystems in the Champagne and Aishihik Traditional Territory for each of three scenarios: "current climate conditions," "low scenario of future climate change by the 2050s," and "high scenario of future climate change by the 2050s." Scale of 1 to $10(0=$ no importance, $1=$ low importance, $10=$ high importance) or don't know. Results shown are the average rank and standard deviation (s.d.) of participants who provided a ranking. The percentage of participants who agree or strongly agree with the statement "this management option is currently being practiced in the Yukon" is also provided. Adaptation options in bold are considered to be "no-regrets" (option is ranked 7 or higher across range of scenarios).

\begin{tabular}{|c|c|c|c|c|}
\hline \multirow[t]{3}{*}{ Adaptation Option } & \multicolumn{2}{|c|}{$\begin{array}{l}\text { Current Current } \\
\text { Practice Importance }\end{array}$} & \multicolumn{2}{|c|}{$\begin{array}{l}\text { Importance Considering } \\
\text { Projected Change } 2050 \mathrm{~s}\end{array}$} \\
\hline & & & Low Scenario & High Scenario \\
\hline & $(\%)$ & $\begin{array}{l}\text { Average } \\
\text { Rank } \\
\text { (s.d.) }\end{array}$ & $\begin{array}{l}\text { Average Rank } \\
\text { (s.d.) }\end{array}$ & $\begin{array}{l}\text { Average Rank } \\
\text { (s.d.) }\end{array}$ \\
\hline $\begin{array}{l}\text { Breed for pest resistance and for a wider tolerance to a range of } \\
\text { climate stresses and extremes in specific genotypes }\end{array}$ & 3 & $5.2(3.2)$ & $6.1(3.0)$ & $6.8(3.1)$ \\
\hline $\begin{array}{l}\text { Adjust harvest schedules to harvest stands most vulnerable to } \\
\text { natural disturbances (e.g., insect outbreaks or fire) }\end{array}$ & 50 & $5.8(3.4)$ & $6.4(3.2)$ & $7.3(3.3)$ \\
\hline $\begin{array}{l}\text { Reduce non-climate stresses to enhance ability of ecosystems to } \\
\text { respond to climate change by managing tourism, recreation, and } \\
\text { grazing impacts }\end{array}$ & 20 & $4.1(3.2)$ & $5.0(3.2)$ & $5.7(3.4)$ \\
\hline $\begin{array}{l}\text { Reduce non-climate stresses to enhance ability of ecosystems to } \\
\text { respond to climate change by regulating atmospheric pollutants }\end{array}$ & 13 & $5.2(3.8)$ & $6.0(3.9)$ & $6.5(4.0)$ \\
\hline $\begin{array}{l}\text { Reduce non-climate stresses to enhance ability of ecosystems to } \\
\text { respond to climate change by restoring degraded areas to } \\
\text { maintain genetic diversity and promote ecosystem health }\end{array}$ & 27 & $5.4(2.8)$ & $6.3(2.9)$ & $6.9(3.1)$ \\
\hline $\begin{array}{l}\text { Plant genotypes that are tolerant of drought, insects, and/or } \\
\text { disease }\end{array}$ & 3 & $5.6(3.0)$ & $6.3(2.6)$ & $7.3(2.4)$ \\
\hline $\begin{array}{l}\text { Reduce disease losses through sanitation cuts that remove } \\
\text { infected trees }\end{array}$ & 20 & $4.8(3.5)$ & $5.3(3.3)$ & $5.6(3.7)$ \\
\hline $\begin{array}{l}\text { Used prescribed burning to encourage regeneration, reduce fire } \\
\text { risk, and reduce forest vulnerability to insect outbreaks }\end{array}$ & 7 & $6.8(2.9)$ & $7.3(2.7)$ & $7.7(2.8)$ \\
\hline $\begin{array}{l}\text { Employ silvicultural techniques to promote forest productivity } \\
\text { and increase stand vigor (i.e., partial cutting or thinning) to } \\
\text { lower the susceptibility to insect attack }\end{array}$ & 44 & $6.4(2.6)$ & $7.2(2.5)$ & $7.4(2.6)$ \\
\hline $\begin{array}{l}\text { Shorten the rotation length to decrease the period of stand } \\
\text { vulnerability to damaging insects and diseases and to facilitate } \\
\text { change to more suitable species }\end{array}$ & 7 & $3.6(3.0)$ & $4.9(3.4)$ & $5.0(3.6)$ \\
\hline
\end{tabular}


Table 7. Judgments of forest practitioners on the importance of adaptation options to conserve and maintain soil and water resources in forest ecosystems in the Champagne and Aishihik Traditional Territory for each of three scenarios: "current climate conditions," "low scenario of future climate change by the 2050s," and "high scenario of future climate change by the 2050s." Scale of 1 to $10(0=$ no importance, $1=$ low importance, $10=$ high importance) or don't know. Results shown are the average rank and standard deviation (s.d.) of participants who provided a ranking. The percentage of participants who agree or strongly agree with the statement "this management option is currently being practiced in the Yukon" is also provided. Adaptation options in bold are considered to be "no-regrets" (option is ranked 7 or higher across range of scenarios).

\begin{tabular}{|c|c|c|c|c|}
\hline \multirow[t]{3}{*}{ Adaptation Option } & \multirow{2}{*}{\multicolumn{2}{|c|}{$\begin{array}{l}\text { Current Current } \\
\text { Practice Importance }\end{array}$}} & \multicolumn{2}{|c|}{$\begin{array}{l}\text { Importance Considering } \\
\text { Projected Change } 2050 \mathrm{~s}\end{array}$} \\
\hline & & & Low Scenario & High Scenario \\
\hline & $(\%)$ & $\begin{array}{l}\text { Average } \\
\text { Rank } \\
\text { (s.d.) }\end{array}$ & $\begin{array}{l}\text { Average Rank } \\
\text { (s.d.) }\end{array}$ & $\begin{array}{l}\text { Average Rank } \\
\text { (s.d.) }\end{array}$ \\
\hline $\begin{array}{l}\text { Minimize soil disturbance through low-impact harvesting } \\
\text { activities }\end{array}$ & 70 & $6.9(2.8)$ & $7.5(2.7)$ & $7.8(2.9)$ \\
\hline $\begin{array}{l}\text { Minimize density of permanent road network to maximize } \\
\text { productive forest area and forest sinks }\end{array}$ & 63 & $7.1(2.8)$ & $7.4(2.7)$ & $7.7(2.8)$ \\
\hline $\begin{array}{l}\text { Deactivate and rehabilitate roads to maximize productive } \\
\text { forest area and forest sinks }\end{array}$ & 56 & $7.3(2.5)$ & $7.6(2.4)$ & $7.7(2.4)$ \\
\hline $\begin{array}{l}\text { Limit harvesting operations to the winter in order to minimize } \\
\text { road construction and soil disturbance }\end{array}$ & 80 & $6.8(2.6)$ & $7.1(2.6)$ & $7.3(2.9)$ \\
\hline $\begin{array}{l}\text { Avoid constructing roads in landslide-prone terrain where } \\
\text { increased precipitation and melting of permafrost may } \\
\text { increase the hazard of slope failure }\end{array}$ & 77 & $7.7(2.6)$ & $8.2(2.5)$ & $8.5(2.4)$ \\
\hline $\begin{array}{l}\text { Maintain, decommission, and rehabilitate roads to minimize } \\
\text { sediment runoff due to increased precipitation and melting } \\
\text { of permafrost }\end{array}$ & 53 & $7.8(2.2)$ & $8.2(2.1)$ & $8.4(2.0)$ \\
\hline $\begin{array}{l}\text { Mitigating the impacts on infrastructure, fish, and potable water } \\
\text { of changes in the timing of peak flow and volume in streams } \\
\text { resulting from more/earlier snow melt }\end{array}$ & 23 & $6.8(2.7)$ & $7.5(2.4)$ & $8.3(2.4)$ \\
\hline
\end{tabular}

with more suitable genotypes (the latter considered more appropriate). Participants commented on the adaptation option to "actively manage forest pests," noting there is little evidence to suggest that this works and little support for such a program if it involved the use of pesticides. It was noted that when the spruce beetle infestation was first documented, it was already so large that little could be done to control its continued expansion. Some also noted that there is no current program to manage forest pests in the Yukon and that current monitoring of forest health is limited and unlikely to be adequate as an early warning detection system, particularly in light of the projected influence of climate change on the population and distribution of forest pests.

Some were in favor of relaxing rules governing the movement of seed stocks (although it was questioned whether or not firm rules actually exist in the Yukon), but only if other options were first examined, long-term research trials were established to inform any changes in policy, and 
Table 8. Judgments of forest practitioners on the importance of adaptation options to conserve and maintain soil and water resources in forest ecosystems in the Champagne and Aishihik Traditional Territory for each of three scenarios: "current climate conditions," "low scenario of future climate change by the 2050s," and "high scenario of future climate change by the 2050s." Scale of 1 to $10(0=$ no importance, $1=$ low importance, $10=$ high importance) or don't know. Results shown are the average rank and standard deviation (s.d.) of participants who provided a ranking. The percentage of participants who agree or strongly agree with the statement "this management option is currently being practiced in the Yukon" is also provided. Adaptation options in bold are considered to be "no-regrets" (option is ranked 7 or higher across range of scenarios).

\begin{tabular}{|c|c|c|c|c|}
\hline \multirow[t]{3}{*}{ Adaptation Option } & \multirow{2}{*}{\multicolumn{2}{|c|}{$\begin{array}{l}\text { Current Current } \\
\text { Practice Importance }\end{array}$}} & \multicolumn{2}{|c|}{$\begin{array}{l}\text { Importance Considering } \\
\text { Projected Change 2050s }\end{array}$} \\
\hline & & & Low Scenario & High Scenario \\
\hline & $(\%)$ & $\begin{array}{l}\text { Average } \\
\text { Rank } \\
\text { (s.d.) }\end{array}$ & $\begin{array}{l}\text { Average Rank } \\
\text { (s.d.) }\end{array}$ & $\begin{array}{l}\text { Average Rank } \\
\text { (s.d.) }\end{array}$ \\
\hline Mitigate climate change through forest carbon management & 6 & $5.0(3.4)$ & $6.1(3.5)$ & $6.6(3.6)$ \\
\hline Increase forested area through afforestation & 16 & $3.9(3.1)$ & $4.7(3.3)$ & $5.3(3.4)$ \\
\hline Reduce forest degradation and avoid deforestation & 37 & $6.1(3.1)$ & $7.0(2.6)$ & $7.6(2.6)$ \\
\hline Enhance forest growth through forest fertilization & 0 & $2.2(2.6)$ & $2.8(3.1)$ & $3.1(3.4)$ \\
\hline $\begin{array}{l}\text { Decrease impact of natural disturbances on carbon stocks through } \\
\text { fire management and pest management }\end{array}$ & 30 & $3.5(3.2)$ & $4.5(3.3)$ & $5.1(3.6)$ \\
\hline Enhance forest recovery after disturbance & 17 & $4.5(3.2)$ & $5.1(3.0)$ & $5.6(3.3)$ \\
\hline Increase the use of forests for biomass energy & 33 & $6.0(2.8)$ & $6.5(2.8)$ & $6.7(3.1)$ \\
\hline $\begin{array}{l}\text { Modify thinning practices (timing, intensity) and rotation length } \\
\text { to increase growth and turnover of carbon }\end{array}$ & 0 & $4.0(3.1)$ & $5.0(3.5)$ & $5.7(3.8)$ \\
\hline $\begin{array}{l}\text { Minimize density of permanent road network to maximize forest } \\
\text { sinks }\end{array}$ & 40 & $6.0(3.4)$ & $6.7(3.3)$ & $7.1(3.3)$ \\
\hline $\begin{array}{l}\text { Maintain, decommission, and rehabilitate roads to maximize } \\
\text { forest sinks }\end{array}$ & 43 & $6.3(3.2)$ & $7.0(3.0)$ & $7.4(3.0)$ \\
\hline $\begin{array}{l}\text { Minimize soil disturbance through low-impact harvesting } \\
\text { activities }\end{array}$ & 70 & $6.4(3.1)$ & $7.3(2.9)$ & $7.6(3.0)$ \\
\hline Fire suppression & 74 & $5.2(3.2)$ & $5.7(3.4)$ & $5.9(3.7)$ \\
\hline
\end{tabular}


Table 9. Judgments of forest practitioners on the importance of adaptation options to maintain and enhance long-term multiple socioeconomic benefits to meet the needs of societies from forest ecosystems in the Champagne and Aishihik Traditional Territory for each of three scenarios: "current climate conditions," "low scenario of future climate change by the 2050s," and "high scenario of future climate change by the 2050s." Scale of 1 to 10 ( $0=$ no importance, $1=$ low importance, $10=$ high importance $)$ or don't know. Results shown are the average rank and standard deviation (s.d.) of participants who provided a ranking. The percentage of participants who agree or strongly agree with the statement "this management option is currently being practiced in the Yukon" is also provided. Adaptation options in bold are considered to be "no-regrets" (option is ranked 7 or higher across range of scenarios).

\begin{tabular}{|c|c|c|c|c|}
\hline \multirow[t]{3}{*}{ Adaptation Option } & \multirow[t]{2}{*}{$\begin{array}{l}\text { Current } \\
\text { Practice }\end{array}$} & \multirow[t]{2}{*}{$\begin{array}{l}\text { Current } \\
\text { Importance }\end{array}$} & \multicolumn{2}{|c|}{$\begin{array}{l}\text { Importance Considering } \\
\text { Projected Change 2050s }\end{array}$} \\
\hline & & & Low Scenario & High Scenario \\
\hline & $(\%)$ & $\begin{array}{l}\text { Average Rank } \\
\text { (s.d.) }\end{array}$ & $\begin{array}{l}\text { Average Rank } \\
\text { (s.d.) }\end{array}$ & $\begin{array}{l}\text { Average Rank } \\
\text { (s.d.) }\end{array}$ \\
\hline $\begin{array}{l}\text { Anticipate variability and change and conduct vulnerability } \\
\text { assessments at a regional scale }\end{array}$ & 33 & $6.1(2.6)$ & $6.9(2.6)$ & $7.6(2.7)$ \\
\hline $\begin{array}{l}\text { Foster learning and innovation, and conduct research to } \\
\text { determine when and where to implement adaptive responses }\end{array}$ & 67 & $7.5(2.4)$ & $7.7(2.3)$ & $8.1(2.3)$ \\
\hline $\begin{array}{l}\text { Diversify forest economy, e.g., explore deadwood product } \\
\text { markets, value-added products }\end{array}$ & 84 & $8.2(1.7)$ & $8.3(1.3)$ & $8.4(1.6)$ \\
\hline Diversify regional economy (non-forest based) & 56 & $8.2(1.3)$ & $8.4(1.5)$ & $8.8(1.4)$ \\
\hline $\begin{array}{l}\text { Diversify the regional economy by promoting non-timber } \\
\text { forest products }\end{array}$ & 54 & $7.0(2.1)$ & $7.8(1.7)$ & $8.2(1.7)$ \\
\hline $\begin{array}{l}\text { Enhance dialog among stakeholder groups to establish } \\
\text { priorities for action on climate adaptation in the forest sector }\end{array}$ & 73 & $7.0(2.5)$ & $7.4(2.2)$ & $7.7(2.4)$ \\
\hline $\begin{array}{l}\text { Protect higher-value areas from fire through "fire-smart" } \\
\text { techniques }\end{array}$ & 90 & $7.7(2.5)$ & $7.9(2.4)$ & $8.1(2.4)$ \\
\hline $\begin{array}{l}\text { Increase amount of timber from salvage logging of fire- or } \\
\text { insect-disturbed stands }\end{array}$ & 86 & $7.2(2.7)$ & $6.9(2.6)$ & $7.1(2.7)$ \\
\hline $\begin{array}{l}\text { Enhance capacity to undertake integrated assessments of } \\
\text { vulnerabilities at various scales }\end{array}$ & 27 & $6.2(2.8)$ & $6.8(2.3)$ & $7.4(2.5)$ \\
\hline $\begin{array}{l}\text { Review forest policies, forest planning, forest management } \\
\text { approaches and institutions to assess our ability to achieve } \\
\text { social objectives under climate change; encourage societal } \\
\text { adaptation }\end{array}$ & 57 & $7.3(2.6)$ & $7.8(2.0)$ & $8.1(2.2)$ \\
\hline $\begin{array}{l}\text { Develop technology to use altered wood quality and tree species } \\
\text { composition, modify wood processing technology }\end{array}$ & 33 & $6.7(2.2)$ & $6.9(1.9)$ & $7.1(2.1)$ \\
\hline $\begin{array}{l}\text { Make choice about the preferred tree species composition for the } \\
\text { future; establish objectives for the future forest under climate } \\
\text { change }\end{array}$ & 7 & $6.9(3.0)$ & $7.3(2.8)$ & $7.6(3.0)$ \\
\hline
\end{tabular}




\begin{tabular}{|c|c|c|c|c|}
\hline $\begin{array}{l}\text { Include risk management in management rules and forest } \\
\text { plans, and develop and enhanced capacity for risk } \\
\text { management }\end{array}$ & 26 & $7.3(2.4)$ & $8.0(1.9)$ & $8.6(1.5)$ \\
\hline $\begin{array}{l}\text { Conduct an assessment of greenhouse gas emissions produced } \\
\text { by internal operations }\end{array}$ & 10 & $5.0(3.4)$ & $5.5(3.3)$ & $5.9(3.4)$ \\
\hline $\begin{array}{l}\text { Increase awareness about the potential impact of climate } \\
\text { change on the fire regime and encourage proactive actions in } \\
\text { regard to fuels management and community protection }\end{array}$ & 83 & $7.8(2.1)$ & $8.3(1.9)$ & $8.4(1.8)$ \\
\hline
\end{tabular}

natural regeneration remained the first priority. Provenance trials have been established in the Yukon, but they are not along a diverse array of climatic and latitudinal gradients, limiting their potential value. Practitioners noted that for many of the options evaluated, they were assuming that it only applied to the "managed" forest, and that this only covered a limited portion of the total forested land base. A large knowledge gap that was identified was the effectiveness of various silvicultural practices and regeneration dynamics north of $60^{\circ}$, highlighting the need for additional research in this area regardless of climate change. Finally, it was noted that several of the adaptation options might be unnecessary given the present small size of the forest industry in the Yukon.

\section{Adaptation options to maintain health and vitality of forest ecosystems}

The applicability of alternative adaptation options to maintain forest health and vitality in the CATT are shown in Table 6 . None of the 10 options were considered important under current climate conditions, two were important under a low scenario of climate change, and four under a high scenario. Forest management activities in the region or in the Yukon were considered to be so small in scale that they would be unlikely to greatly influence forest health and vitality. Some suggested that because so little of the Yukon contains commercially valuable forest and harvest levels are so small, there is no need for intensive forestry. Although many noted the importance of efforts to renew forests, particularly in areas affected by spruce beetle, opinions differed over the management practices that might be implemented, if any, to encourage forest renewal.

Practitioners had some experience with the adjustment of harvest schedules to harvest those stands most vulnerable to natural disturbances (e.g., insect outbreaks or fire). Often the older stands, which are seen as more vulnerable, are targeted for harvesting first. However, there was some disagreement over the effectiveness of this management practice in maintaining the health and vitality of the Yukon's forest ecosystems. Some practitioners said they would support planting genotypes that were more tolerant of drought, insects, or disease provided that they are not from exotic species. They also suggested that it would make sense to reforest with local seed taken from trees that have not exhibited drought stress. Activities such as using prescribed fire for silviculture have been recommended but not implemented in the Yukon (due to risk, possible cost, and potential liability), and one questioned the applicability of prescribed burning to boreal forests because of potential loss of thin organic soil horizons.

Options such as shortening the rotation length and using silvicultural techniques such as thinning were noted to be appropriate only in intensively managed stands, and it was pointed out that plantation forestry may not be widely supported by the public. The option of shortening the rotation length to decrease the period of stand vulnerability to damaging insects and diseases and to facilitate change to a range of species was not rated highly. It was noted there are no established policies regarding rotation length in the Yukon. Potential issues associated with targeting older stands for harvesting were noted to be (1) public support for targeting older stands and (2) the failure to address pathogens and pests associated with earlier successional stages.

\section{Adaptation options to conserve and maintain soil and water resources}

Adaptation options to conserve and maintain soil and water resources were ranked highly by most practitioners (Table 7). Of the seven options 
Table 10. Judgments of forest practitioners on the importance of options to adapt the present legal, institutional, and economic framework for forest conservation and sustainable management for each of three scenarios: "current climate conditions," "low scenario of future climate change by the 2050s," and "high scenario of future climate change by the 2050s." Scale of 1 to $10(0=$ no importance, $1=$ low importance, $10=$ high importance) or don't know. Results shown are the average rank and standard deviation (s.d.) of participants who provided a ranking. The percentage of participants who agree or strongly agree with the statement "this management option is currently being practiced in the Yukon" is also provided. Adaptation options in bold are considered to be "no-regrets" (option is ranked 7 or higher across range of scenarios).

Adaptation Option
Current Current

Practice Importance
Importance Considering

Projected Change 2050s

Low Scenario High Scenario

(\%) Average Rank Average Rank Average Rank (s.d.) (s.d.) (s.d.)

Provide long-term tenures.

10

$4.9(3.0)$

$5.0(3.1)$

$5.3(3.3)$

Relax rules governing the movement of seed stocks from one area to another; examine options for modifying seed transfer

$13 \quad 4.3(2.8)$

$5.3(3.1)$

limits and systems.

Provide incentives and remove barriers to enhancing carbon sinks and reducing greenhouse gas emissions.

Provide opportunities for forest management activities to be 3 included in carbon trading systems (as outlined in Article 3.4 of Kyoto Protocol).

Practice adaptive management—a management approach that rigorously combines management, research, monitoring, and means of changing practices to gain credible information and modify management activities by experience.

Measure, monitor, and report on indicators of climate change and sustainable forest management to determine the state of the forest and identify when critical thresholds are reached.

Evaluate the adequacy of existing environmental and biological monitoring networks for tracking the impacts of climate change on forest ecosystems, identify inadequacies/ gaps in these networks, and identify options to address them.

Support research on climate change, climate impacts, and climate adaptations and increase resources for basic climate change impacts and adaptation science.

Support knowledge exchange, technology transfer, capacity building, and information sharing on climate change; maintain or improve capacity for communications and networking.
10

$6.7(2.8) \quad 7.3(2.6) \quad 7.6(2.7)$

$4.8(2.8) \quad 5.3(2.7) \quad 5.5(2.9)$

$40 \quad 8.5(2.1) \quad 9.0(1.4) \quad 9.4(1.0)$

40

$7.8(2.5)$

$8.2(2.2)$

$8.6(2.0)$

$10 \quad 7.7(2.8)$

$7.9(2.5)$

$8.3(2.5)$

74

$8.0(2.3)$

$8.4(1.8)$

8.7 (1.7)

77

$8.2(2.50$

$8.4(2.1)$

8.7 (1.9) 


\begin{abstract}
Incorporate new knowledge about the future climate and forest vulnerability into forest management plans and policies.
\end{abstract}

27

$8.2(2.4)$

$8.6(1.9)$

$9.0(1.6)$

Involve the public in an assessment of forest management adaptation options.
$63 \quad 7.4(2.6) \quad 7.7(2.5) \quad 7.8(2.5)$ considered, four were considered to be important to implement under current climate conditions, seven under a low scenario of climate change, and seven under a high scenario. Many comments suggested that these options are important for reasons other than mitigating climate change impacts. With the exception of one option, practitioners agreed that these options were already being practiced in the Yukon to minimize the impact of forestry activities. To date, most harvesting in the Yukon has been done when the ground is frozen, and soil disturbance is usually minimal, except when operations are not completed before spring melt. However, summer access has been proposed in dry areas and even when harvesting is done in winter, roads are still required. Some suggested that current engineering specifications will reduce disturbance, but others had observed instances of inadequate road design, poor alignment choices, lack of ditching and culverts, and poor construction methods, resulting in gully erosion down roads, gully erosion across roads, and road bed collapses. More work is needed on the effectiveness of operational practices to ensure that they are meeting management objectives.

Road networks in the Yukon are limited and offroad access into harvesting areas is usually restricted. Logging roads are deactivated to restrict access by hunters, rather than to increase the land surface suitable for forest growth. In-block roads and trails are often planted or treated to promote natural reforestation by wind-blown seed. Several suggestions were also made for ways to improve management practices to conserve and maintain soil and water resources, including developing access management plans at the landscape planning level rather than at the development planning level. Some expressed concern over summer access in dry areas because these usually have very thin organic soil horizons that are negatively impacted by roads and harvesting operations. Others encouraged gaining more experience with summer harvesting because of observations that blocks with more mineral soil exposure green up more quickly from natural regeneration.

\section{Adaptation options to maintain the contribution of forest ecosystems to global carbon cycles}

None of the options to maintain the contribution of forest ecosystems to global carbon cycles were considered important under current climate conditions, three were thought to be important under a low scenario of climate change, and four under a high scenario (Table 8). Some participants considered forest carbon management important, regardless of climate change and thought that the paradigm of forest management in the Yukon would shift significantly in the next 50 years because of the important role that northern boreal forests play in global carbon cycles. Some thought that managing for carbon sinks would not have any drastic influence on atmospheric greenhouse gas concentrations because there is insufficient forest management activity in the Yukon to impact on carbon sinks; therefore, efforts to emphasize carbon management would be motivated more by politics than by science.

Although some were of the opinion that maintaining forested areas in general is a valid way to minimize the impacts of climate change, deforestation from urbanization or agriculture was not considered to be a significant issue in the region either presently or in the foreseeable future. It was also noted that avoiding deforestation and reducing forest degradation is happening by default, but is not current policy and that little potential exists for afforestation in the CATT.

Fertilization (the only no-go option that was identified) was not considered to be an effective way to enhance carbon sequestration because forest growth in the region is limited more by soil temperature than nutrients and because fertilization is not considered to be either socially or economically feasible. Although some participants 
considered fire suppression to be important to protect the carbon in forest soils, others questioned the appropriateness and effectiveness of long-term fire suppression as a means to enhance carbon sinks. Some thought that forest practitioners have a tendency to overestimate the ability to control fire and insects. There was, however, support for suppression efforts to protect communities, infrastructure, and other values at risk.

A few participants clarified their opinion on the use of forests for biomass energy, seeing the use of mill waste biomass for energy production as a viable option for the use of salvaged dead trees, but not live trees. Others noted that fuelwood production was a good example of an industry currently active in the region and elsewhere in the Yukon that is consistent with this adaptation option. Some questioned whether protecting carbon in large mature trees and wetlands would have more of an impact on carbon stores in the Yukon than promoting carbon sequestration in young forests because the average growth of young trees in the Yukon is much less than elsewhere.

\section{Adaptation options to maintain and enhance long-term multiple socioeconomic benefits to meet the needs of society from forest ecosystems}

Participants were generally supportive of the adaptation options under this category (Table 9). Out of the 15 options that were considered, 10 were considered to be important under current climate conditions, 10 under a low scenario of climate change, and 14 under a high scenario. Many supported the option of enhancing dialog among stakeholder groups to establish priorities for action on adaptation, but indicated that locals should have more say in the setting of priorities. Fire-smart activities around high-value areas were broadly supported; however, some questioned how effective this was and suggested it might be being used to justify harvesting in areas otherwise unacceptable for logging.

Many participants considered diversifying the nonforest-based regional economy to be important; however, it was noted that forestry is relatively new to the region and itself provides an opportunity to diversify the regional economy. The option to increase the amount of timber from salvage logging is already the focus of forestry planning efforts. Many supported salvage harvesting but with some important qualifiers, one being the scale of the planned harvest. Some noted that any salvage harvests must ensure that other values associated with disturbed stands are considered. Others were frustrated that planning for the salvage harvesting had taken so long and questioned (1) if salvage is sustainable in an economic sense, (2) if there is a market for the wood, and (3) if harvesting activities will reach the harvest level that has been set. It was suggested that economic diversification should be a higher priority than developing new technology in a rapidly changing business and environmental climate. On the contrary, it was noted that technology development makes good sense in a jurisdiction with a relatively low harvest level.

\section{Options to adapt the present legal, institutional, and economic framework for forest conservation and sustainable management to incorporate climate change considerations}

Most of the options within this category were judged to be important (Table 10). Out of the 11 options that were considered, seven were considered important under current climate conditions, eight under a low scenario of climate change, and eight under a high scenario. Many commented on the option of providing long-term tenures, which was not ranked highly for any of the scenarios. Longterm tenures are not currently issued in the Yukon although they are frequently requested by the forest industry. Practitioners suggested that if they were to be issued, they would need to be flexible to adapt to changes in the forested landbase that may result from climatically driven changes in natural disturbance regimes.

At the time when this study was being carried out, Canada was considering whether or not to include the $\mathrm{CO}_{2}$ effects of forest management in their national greenhouse gas inventories as outlined in Article 3.4 of the Kyoto Protocol (United Nations Framework Convention on Climate Change (UNFCCC) 1997). Many participants were unsure of the details and potential implications of this policy decision. Some believed that policies to support forest management activities that enhance carbon sinks and maintain carbon stores were a good idea, particularly if there was an opportunity to participate in a trading system. Others felt this would be imprudent if it meant additional responsibilities would be created to offset carbon sources because of natural disturbances, which are expected to 
increase. Most agreed this was a policy that would need to be carefully considered and studied in greater detail.

Practicing adaptive management was seen to be important, and many noted that efforts were starting to be made in this area. There were three suggestions for adaptive management in the region: (1) any such efforts would need to be kept simple to be meaningful at the community level, (2) efforts should be made to involve community members in research and monitoring activities, and (3) documentation would need to be greatly improved before it would be possible to gain credible information by experience to modify management activities. An evaluation of the adequacy of existing environmental monitoring networks for tracking climate change impacts should take place before efforts are made to measure, monitor, and report on indicators of climate change and sustainable forest management. There were some doubts that current monitoring activities will allow us to proactively adapt management to keep up with climate change. It was also noted that efforts need to be made within CAFN to get traditional knowledge into a usable format, noting the existence of older information that would provide insight into local climate and environmental change. Additional research on climate change, impacts, and adaptations was also seen to be important. Involving the public in an assessment of adaptation options was also supported, with the qualifier that the public would need to be provided with the necessary background information to enable them to respond in a meaningful way.

Lastly, it was suggested that adaptation may need to occur more at the family level than at the regional level, although both are important, and suggested there is a need to provide options for families and businesses to innovate and to buffer the risk of their trials.

\section{DISCUSSION}

The following discussion applies the results from this project to the primary research questions posed in the introduction of this paper.

\section{Have Forest Practitioners Observed Changes in Various Attributes of Environmental, Social, and Economic Systems Monitored Over the Past 20 Years that They Attribute to Recent Climate Warming?}

A number of changes in the attributes of environmental, social, and economic systems attributable to recent climate warming had been noted over the past 20 years. Evidence of climate change impacts from both documented scientific observations (e.g., Farnell et al. 2004, Fleming 2005, Hogg and Wein 2005, Juday et al. 2005, Danby and Hik 2007, Ogden 2007) and undocumented local knowledge are abundant (documented sources of local knowledge, e.g., Legend Seekers (2001) and McKinnon (2006), are less abundant) and support the judgments provided by the practitioners on the sensitivity of the links between socioeconomic and environmental systems in this region and climate change.

\section{What Factors Do Forest Practitioners Perceive to Be Contributing to the Adaptive Capacity of the Forest Sector and Forest-Based Communities to Climate Change?}

Societies and communities dependent on natural resources need to enhance their capacity to adapt to the impacts of future climate change, particularly when such impacts could lie outside their realm of experience. Although the current availability of scientific knowledge on climate change was considered the foremost factor contributing to the enhancement of adaptive capacity in the region, participants did not consider any of the listed factors as being particularly prevalent. Insights from adaptive and community-based resource management suggest that social learning, specifically in relation to the acceptance of adaptive strategies, is an effective way to cope with environmental change (Tompkins and Adger 2004). It is likely that this study itself contributed to the adaptive capacity of the 30 local practitioners who participated by increasing their awareness of the adaptation options and the informed judgments of their colleagues on the applicability of these options to forest management in this region. Further efforts to enhance adaptive capacity in the region are, however, warranted. Efforts to enhance any of the factors listed in Table 2 are likely to be beneficial. As rigid and inflexible policies can enhance vulnerability, additional work to determine where 
policy and regulatory changes may be needed to ensure adaptation is possible and effective also seems warranted. Such an exercise is opportune given the adaptive management framework that is embedded within the SFMP. In addition, designing and implementing "active" adaptive management experiments, such as operational trials that have a strong element of community-level participation, may make a significant contribution to adaptive capacity in the region.

\section{To What Degree Are the Forest Sector and Forest-Dependent Communities Vulnerable to the Impacts of Climate Change?}

Adaptation options may be developed to address areas of vulnerability. An understanding of current and future vulnerability is, therefore, critical to the development and evaluation of options (Burton 1997). Currently, the region is considered by practitioners to be highly vulnerable to a number of climate change impacts, and vulnerability was considered to increase with increasing warming for all of the potential impacts of climate change that were assessed.

\section{What is the Importance of Alternative Adaptation Options to Achieving Objectives of Sustainable Forest Management under Low and High Scenarios of Climate Change? Are Any of these Adaptation Options Currently Being Practiced?}

Overall, $29 \%$ of the 84 options were considered to be important to implement under current climate conditions, $43 \%$ of options were important under a low scenario of warming, and $57 \%$ under a high scenario. The importance of implementing the vast majority (98\%) of the adaptation options was seen to increase with greater warming.

We compared the findings of this regional study to a broader study that documented the informed judgments of practitioners from the Yukon and Northwest Territories of Canada. This broader study recommended that the evaluation of adaptation options be confined to particular planning areas where management objectives are set, a recommendation that we put into action in this study (Ogden and Innes 2007a). In both studies, practitioners similarly considered some adaptation options to make sense to implement regardless of whether or not climate change is a consideration in forest management plans. In addition, practitioners in both studies did not change their judgments of the importance of implementing some adaptation options between low and high scenarios of warming. Unlike the regional study where the importance of nearly all options was considered to increase with warming, the considered importance of some adaptation options decreased with warming in the broader study. In addition, the relative importance assigned to adaptation options differed in some cases between the broader study and this regional study.

Despite the clear management objectives for the CATT, practitioners differed over the importance of implementing some of the options. It seems that climate change may be altering visions of the future forest and expectations on what forest managers can realistically achieve. Climate change may also be altering how practitioners perceive trade-offs in social, economic, and environmental dimensions of forest management, and additional research is needed on how the balance between these oftencompeting objectives is changing. As the forest management plan is a reflection of communitydirections for the future forest, any such research must have strong community involvement and must lie within the adaptive management framework of the SFMP.

To assess the incremental costs and benefits of adaptation, it is essential to have an understanding of current management practices that may contribute to reducing vulnerability to climate change (Ohlson et al. 2005). We were surprised at the lack of consensus on which of the 84 adaptation options were currently being practiced in the Yukon. Interestingly, of the 24 no-regrets options identified in this study, 18 are reflected in current policy (Ogden and Innes 2008); however, only 11 are currently being practiced according to more than two-thirds of the participants in this study. This may be attributable to differences in opinion on the definition of current practice. For example, as there is currently very little forestry activity happening in the Yukon, some of the options (e.g., minimize fragmentation, maintain carbon sinks, etc.) are happening by default. Some may, therefore, consider these to be current practice whereas others view practices as being more formal policies, regulations, or land-use designations. An alternative explanation may be the lack of formal implementation-oriented policies and procedures 
manuals or a discrepancy between what is in existing manuals and what is actually put into practice. The incremental costs and benefits of adaptation are, therefore, associated with efforts that are required to implement approximately half of the no-regrets options that were identified in this study. We believe that these options are feasible, sustainable, pragmatic, widely acceptable, and realistically attainable. It is also our opinion that these options are not likely to be maladaptive. The implementation of these additional measures, alongside careful monitoring to assess overall success of management activities and adaptations in reaching local management objectives, is a realistic goal.

\section{What Management Options are Likely to Perform Well Across a Range of Potential Future Climate Change Scenarios?}

As the adaptation options considered here were structured according the objectives of the Montreal Process, any management options viewed as important might be considered to be "win-win" policies, as they reduce vulnerability to climatic change while simultaneously addressing fundamental objectives of sustainable forest management. Practitioners identified 24 no-regrets options deserving implementation under both current and future climates. Practitioners identified 12 options that were not considered important under current climate conditions but were important under low and high scenarios of warming. Only one no-go adaptation option was identified: the use of fertilization to enhance forest growth. The majority of adaptation options for the conservation and maintenance of soil and water resources, the maintenance and enhancement of long-term multiple socioeconomic benefits to meet the needs of societies, and the adoption of the present legal, institutional, and economic framework for forest conservation and sustainable management were considered important. Other objectives-conservation of biological diversity, maintenance of productive capacity, maintenance of forest health and vitality, maintenance of the contribution to global carbon cycles-had very few "no regrets" options associated with them, which we believe to be an indication of a lack of consensus on how to adapt forest management policies and practices to achieve these objectives in light of climate change. Therefore, it appears that some of the criteria appear to bring out more differences in opinion among the different practitioners whereas other criteria may have fewer vested interests or conflicts associated with them. Nearly half of the practitioners in this study indicated that they work to achieve a balance between multiple management objectives, whereas the other half indicated that their focus is on one of the four pillars of sustainable forest managementthe environmental pillar. Therefore, it would not be surprising to find areas where there are conflicting views on adaptation options between these groups.

\section{Is the Framework Suggested by Ogden and Innes (2007b) Useful to an Evaluation of Adaptation Options in a Regional Forest Management Context?}

We received much more positive feedback than negative on the utility of the sessions and workbooks. We believe this research was successful in documenting the current judgments of practitioners on climate change adaptation and that it provides insight into the readiness of practitioners to engage in adaptive strategies. This study created new understanding on the applicability of measures to adapt to climate change in a regional context. Exposing practitioners to adaptation-related considerations has contributed to building a foundation for incorporating climate change considerations into forest management and planning-related decisions. Practitioners gained practical experience in structured decision making and in developing and evaluating alternative climate change adaptation options, and indicated that they found the study provided a useful learning opportunity. Ultimately, this research identified 24 locally appropriate adaptation options considered by forest practitioners to be important to implement to achieve the regional goals and objectives of the forest management in light of climate change. We believe these options provide a reasonable starting point for climate change adaptation, and the results should inform decision making under the adaptive management framework of the SFMP.

\section{Study Limitations}

Forest practitioners provided informed judgments of the importance of alternative adaptation options only for areas currently subject to or proposed for forest development planning in the CATT. The study did not explore judgments of the importance of implementing different adaptation options for 
other landscape zones (e.g., the conservation forest management zone) in this region. Because these zones have different management objectives, it is reasonable to expect that adaptation options would be evaluated differently.

Although the knowledge held by forest practitioners provides insights into practices that are considered to be important to achieving management objectives in light of climate change, the recommendations are only a starting point. Because of the uncertainties associated with climate change, it is essential that any adaptations that are implemented be closely monitored to determine how successful they are in enabling management objectives to be achieved. It is essential that an effective adaptive management framework be in place to make adjustments in management practices when objectives are not being met.

In addition, case studies are not designed to optimize the production of generalizations (Stake 1995); therefore, caution should be taken before the results of this study are applied elsewhere. Additional work to test this framework in other regional contexts is needed to determine if similar results are generated. Practical experience is needed in identifying and implementing robust adaptations in different geographical contexts to enhance our broader understanding of the applicability of these options and in what circumstances they may be maladaptive.

Lastly, we wish to put forward the expectation that management objectives will be able to be reached in all cases with the adoption of adjustments to forest management policies and practices. It is probable that climate change will result in certain thresholds being surpassed that, regardless of the intensity of management efforts, will prohibit the ability to achieve certain objectives. In these cases, we suggest that the management objectives themselves need to be revisited.

\section{CONCLUSIONS}

We suggest that a logical starting point for climate change adaptation in a forest management context is to identify and implement management practices and policies that have a greater likelihood of achieving forest management objectives across the wide range of potential climate futures. This research suggests an approach to identifying locally appropriate adaptation options by tapping into the experiential knowledge base of local forest practitioners while, at the same time, building capacity within a local practitioner community to implement the results. The practitioners involved in this study identified a number of adaptation options that are considered to be important to implement to achieve regional goals and objectives of forest management in light of climate change. This proactive approach to identifying and evaluating "no regrets" adaptation options is intended to inform decision making. Because of the nature of a judgments-based study and the uncertainties posed by climate change, it is essential that any changes to management practices that may be contemplated by decision makers as a result of this study be implemented under an effective adaptive management framework where the effects of treatments are continually monitored and adjustments made in management practices when objectives are not being met. Additional work to test this framework in other regional forest management planning contexts is needed to determine if similar results are generated and the reasons for any differences; this would aid in the development of generalizations.

Responses to this article can be read online at: http://www.ecologyandsociety.org/voll4/iss //art11/ responses/

\section{Acknowledgments:}

The financial support of the Social Sciences and Humanities Research Council under the Canada Graduate Scholarship program, the Model Forest Special Project Area Program, Champagne and Aishihik First Nations Government, the Government of Yukon, and the National Science Foundation's Climate Decision-making Centre toward this research is gratefully acknowledged. The sessions were facilitated by Dan Ohlson. The project planning team consisted of Aynslie Ogden, John Innes, Dan Ohlson, Roger Brown, Susan Skaalid, Gary Miltenberger, and Tim McDaniels. Members of the local Forestry Research and Monitoring Technical Working Group provided invaluable feedback on the project proposal and the practitioner invitation list. Special acknowledgements to Dan Ohlson for his valuable review and comments on the workbook, and to Dan Ohlson and Tim McDaniels for their comments on the draft manuscript. 


\section{LITERATURE CITED}

Arctic Climate Impact Assessment (ACIA). 2004. Impacts of a warming Arctic: Arctic climate impact assessment overview report. Cambridge University Press, Cambridge, UK.

Alsek Renewable Resource Council (ARRC). 2004. Strategic Forest Management Plan: Community Directions for a Sustainable Forest. Whitehorse, Yukon, Canada.

Babbie, E., and L. Benaquisto. 2002. Fundamentals of social research. Nelson, Thompson Canada Limited, Scarborough, Ontario, Canada.

Berkes, F., and D. Jolly. 2002. Adapting to climate change: social-ecological resilience in a Canadian western Arctic community. Conservation Ecology 5(2):18. [online] URL: http://www.ecologyandsociety. org/vol5/iss2/art18/.

Bonsal, B. R., T. D. Prowse, and A. Pietroniro. 2003. An assessment of global climate modelsimulated climate for the western cordillera of Canada (1961-90). Hydrological Processes 17 (18):3703-3716.

Burn, C. R., E. Barrow, and B. Bonsal. 2004. Climate change scenarios for Mackenzie River valley. Indian and Northern Affairs Canada, Northern Water Resources Division, Northwest Territories Region. Yellowknife, Northwest Territories, Canada.

Burton, I. 1997. Vulnerability and adaptive response in the context of climate and climate change. Climatic Change 36(1/2):185-196.

Burton, I., S. Huq, B. Lim, O. Pilifosova, and E. L. Schipper. 2002. From impacts assessment to adaptation priorities: the shaping of adaptation policy. Climate Policy 2:145-159.

Burton, I., and B. Lim. 2005. Adaptation policy framework for climate change. Cambridge University Press, Cambridge, UK.

Chapin, F. S. III, M. Hoel, S. R. Carpenter, J. Lubchenco, B. Walker, T. V. Callaghan, C. Folke, S. A. Levin, K. G. Maler, C. Nilsson, S. Barrett, F. Berkes, A. S. Crepin, K. Danell, T. Rosswall, D. Starrett, A. Xepapadeas, and S. A. Zimov. 2006. Building resilience and adaptation to manage
Arctic change. Ambio 35(4):198-202.

Clarke, D., and S. Slocombe. 2004. Re-negotiating science and protected areas: lessons from grizzly bear conservation in the southwest Yukon, Canada. Pages 33-53 in G. Humphrys and M. Williams, editors. Presenting and representing environments. GeoJournal Library 81, Springer.

Danby, R., and D. Hik. 2007. Variability, contingency and rapid change in recent subarctic alpine tree line dynamics. Journal of Ecology 95 (2):352-363.

Dowlatabadi, H. 2002. Global change: much more than a matter of degrees. Meridian Spring/ Summer:8-12.

Dowlatabadi, H. 2007. On integration of policies for climate and global change. Mitigation and Adaptation Strategies for Global Change 12:651663.

Easterling, W. E., W. H. Hurd, and J. B. Smith. 2004. Coping with global climate change: the role of adaptation in the United States. Pew Centre on Global Climate Change, Arlington, Virginia, USA.

Farnell, R., G. Hare, E. Blake, V. Bowyer, C. Schweger, S. Greer, and R. Gotthardt. 2004. Multidisciplinary investigations of alpine ice patches in southwest Yukon, Canada: paleoenvironmental and paleobiological investigations. Arctic 57:274259.

Fleming, S. W. 2005. Comparative analysis of glacial and nival streamflow regimes with implications for lotic habitat quantity and fish species richness. River Research and Applications 21:363-379.

Folke, C., J. Colding, and F. Berkes. 2002. Synthesis: building resilience and adaptive capacity in social-ecological systems. Pages 352-357 in F. Berkes, J. Colding, and C. Folke, editors. Navigating social-ecological systems: building resilience of complexity and change. Cambridge University Press, Cambridge, UK.

Ford, J., T. Pearce, B. Smit, J. Wandel, M. Allurut, K. Shappa, H. Ittusujurat, and K. Qrunnut. 2006. Reducing vulnerability to climate change in the Arctic: the case of Nunavut, Canada. Arctic 60(2):150-166. 
Garbutt, R. 2005. Yukon 2005 Forest health report. Natural Resources Canada, Pacific Forestry Service and Government of Yukon, Energy Mines and Resources, Victoria, British Columbia, Canada.

Government of Yukon and Champagne and Aishihik First Nations. 2007. Integrated landscape plan for the Champagne and Aishihik traditional territory. Government of Yukon and Champagne and Aishihik First Nations, Whitehorse, Yukon. [online] URL: http://www.emr.gov.yk.ca/f orestry/planning strategic.html.

Gunderson, L., and C. Holling. 2002. Panarchy: understanding transformations in human and natural systems. Island Press, Washington, D.C., USA.

Hare, W. L., and M. Meinshausen. 2006. How much warming are we committed to and how much can be avoided? Climatic Change 75(1-2):111149.

Hogg, E. H., and R. W. Wein. 2005. Impacts of drought on forest growth and regeneration in the southwestern Yukon, Canada. Canadian Journal of Forest Research 35(9):2141-2150.

Huq, S., F. Yamin, A. Rahman, A. Chatterjee, X. Yang, S. Wade, V. Orindi, and J. Chigwada. 2005. Linking climate adaptation and development: a synthesis of six case studies from Asia and Africa. In F. Yamin and S. Huq, editors. Vulnerability, adaptation and climate disasters. Institute of Development Studies Bulletin 36(4):117-122.

Intergovernmental Panel on Climate Change (IPCC). 2001. Climate change 2001: synthesis report: third assessment report of the Intergovernmental Panel on Climate Change. Cambridge University Press, Cambridge UK and New York, New York, USA.

Juday, G. P., V. Barber, P. Duffy, H. Linderhorm, S. Rupp, S. Sparrow, E. Vaganov, and J. Yarie. 2005. Forests, land management and agriculture. Arctic climate impact assessment: scientific report. Cambridge University Press, Cambridge, UK.

Kandlikar, M., J. Risbey, and S. Dessai. 2005. Representing and communicating deep uncertainty in climate-change assessments. Geosciences $\mathbf{3 3 7}$ (4):443-455.
Legend Seekers. 2001. An assessment of documented Yukon First Nations traditional and local knowledge and perspectives on the impacts of climate change within the Yukon Territory and northern British Columbia. Technical report: northern climate exchange gap analysis project. Northern Climate Exchange, Whitehorse, Yukon, Canada.

Lemmen, D., and F. Warren, editors. 2004. Climate change impacts and adaptation: a Canadian perspective. Climate Change Impacts and Adaptation Directorate, Natural Resources Canada, Ottawa, Ontario, Canada.

Lempert, R. J., S. W. Popper, and S. C. Bankes. 2003. Shaping the next one hundred years: new methods for quantitative, long-term policy analysis. RAND Corporation, Santa Monica, California, USA.

Lim, B., and E. Spanger-Siegfried, editors. 2005. Adaptation policy frameworks for climate change: developing strategies, policies and measures. United Nations Development Programme, Cambridge University Press, New York, New York, USA.

McKinnon, A. 2006. Climate change in our backyard workshop proceedings. Alsek Renewable Resource Council and Champagne and Aishihik First Nations, Haines Junction, Yukon, Canada.

Montreal Process Working Group. 1999. The Montreal Process-explanatory brochure of the Montreal Process. [online] URL: http://www.mpci. org/rep-pub/1995/santiago e.html.

Moss, R. H., and S. H. Schneider. 2000. Uncertainties in the IPCC TAR: recommendations to lead authors for more consistent assessment and reporting. Pages 33-51 in R. Pachauri, T. Taniguchi, and K. Tanaka, editors. Guidance: papers on the cross cutting issues of the third assessment report of the IPCC. World Meteorological Organization, Geneva, Switzerland.

Newton, J., C. D. Paci, and A. E. Ogden. 2005. Climate change and natural hazards in northern Canada: Integrating indigenous perspectives with government policy. Mitigation and Adaptation Strategies for Global Change 10:541-571.

O'Brien, K. L., and R. M. Leichenko. 2000. Double exposure: Assessing the impacts of climate 
change within the context of economic globalization. Global Environmental Change 10 (3):221-232.

Ogden, A. E. 2007. Forest Management in a Changing Climate: Building the Environmental Information Base for the Southwest Yukon. Forestry Chronicle 83(6):806-809.

Ogden, A. E., and J. L. Innes. 2007a Perspectives of forest practitioners on climate change adaptation in the Yukon and Northwest Territories of Canada. Forestry Chronicle 83(4):557-569.

Ogden, A. E., and J. L. Innes. 2007b. Incorporating climate change adaptation considerations into forest management and planning in the boreal forest. International Forestry Review 9(3):713-733.

Ogden, A. E., and J. L. Innes. 2008. Climate change adaptation and regional forest planning in southern Yukon, Canada. Mitigation and Adaptation Strategies for Global Change $\mathbf{1 3}$ (8):833-861. [online] URL: http://www.springerlink. com/content $/ \mathrm{m} 5 \mathrm{v} 68317 \mathrm{w} 3285282 / ? \mathrm{p}=$ df0848d0637547468d3c44b09f0f091e\&pi=6.

Ohlson, D. W., G. A. McKinnon, and K. G. Hirsch. 2005. A structured decision-making approach to climate change adaptation in the forest sector. The Forestry Chronicle 81(1):97-103.

Patwardhan, A. 2006. Assessing vulnerability to climate change: the link between objectives and assessment. Current Science 90(3):376-383.

Smit, B., and O. Pilifosova. 2003. From adaptation to adaptive capacity and vulnerability reduction. Pages 9-28 in J. B. Smith, R. J. T. Klein, and S. Huq, editors. Climate change, adaptive capacity and development. Imperial College Press, London, UK.

Spittlehouse, D. L., and R. B. Stewart. 2003. Adaptation to climate change in forest management. British Columbia Journal of Ecosystems and Management 4(1):1-11.

Stake, R. E. 1995. The art of case study research. Sage Publications, Thousand Oaks, California, USA.
Tompkins, E. L., and W. N. Adger. 2004. Does adaptive management of natural resources enhance resilience to climate change? Ecology and Society 9(2): 10. [online] URL: http://www.ecologyandsoc iety.org/vol9/iss2/art10/.

United Nations Framework Convention on Climate Change (UNFCCC). 1997. The Kyoto protocol. [online] URL: http://unfccc.int/.

Wortley, D. 2003. Community-based forest management planning in the Yukon: the difficulties of government transfer of responsibility and authority to community agencies. Thesis, Department of Renewable Resources, University of Alberta, Edmonton, Alberta, Canada.

Yohe, G., and R. S. J. Tol. 2002. Indicators for social and economic coping capacity: moving toward a working definition of adaptive capacity. Global Environmental Change 12:25-40. 
APPENDIX 1. Criteria for the conservation and sustainable management of temperate and boreal forests as defined by the Montreal Process and endorsed through the Santiago declaration in 1995. Source: Montreal Process Working Group 1999.

1. Conservation of biological diversity

2. Maintenance of the productive capacity of forest ecosystems

3. Maintenance of forest ecosystem health and vitality

4. Conservation and maintenance of soil and water resources

5. Maintenance of forest contributions to global carbon cycles

6. Maintenance and enhancement of long-term multiple socioeconomic benefits to meet the needs of societies

7. Legal, institutional, and economic framework for forest conservation and sustainable management 